\title{
THE NEXUS BETWEEN INVESTMENT AND INTEREST RATE: NEW DIMENSIONS FOR PAKISTAN
}

\author{
Nooreen Mujahid* \\ Muhammad Noman \\ Nargis $^{* * *}$
}

\begin{abstract}
The nexus between investment and interest rate is always considered essential to analyze the economic activity as these variables are important economic indicators in defining macroeconomic activity. However, the unchanged condition of investment in Pakistan has raised the cost of investment and crates uncertainty in investors. The paper investigates the link between rate of interest and investment to incorporate a new dimension of call money rate that may enhance the investment opportunities in Pakistan, employing time series analysis for the time span of 1973 - 2015. The ARDL Bound Testing Approach and ECM are employed to capture both the long and short-run dynamics of the variables in the model. The results of the study indicate that the call money rate has significant effect on investment and thus on economic growth. Therefore, the preparation and implementation of financial policies may increase the investmentfriendly rate of interest to stimulate economic growth in Pakistan.
\end{abstract}

Keywords: Investment, Income, Interest rate, call money rate, ARDL

\section{Introduction}

Variations in interest rate can reveal the rudimentary economic situation specifically the macroeconomic activity. It affects GDP growth, inflation, employment, international payments, economic development etc. Hence, any alteration in interest rate is the significant factor to arbiter the condition of the economy. The study is an attempt to analyze the trend analysis of interest rate and to predict the macroscopic economic conditions in Pakistan.

Economists consider interest rate as an important factor to link the money market, total public savings and investment. It is the opportunity cost of investment that affects investment activities and determines the expected scale of investment to forecast the desired level of savings. However, an increment in the rate of interest surges the investment cost and lowers income of investors. This inevitably creates uncertainty among investors and sedates them to draw back from their area of investment, so that the investment demand declines in the economy. The bond market is also highly impulsive to the changes in the interest rate as there is inverse association between interest rate and bond prices

\footnotetext{
* Nooreen Mujahid, Ph.D., Associate Professor, Department of Economics, University of Karachi

*** Muhammad Noman, Senior Lecturer, Department of Finance and Economics, Faculty of Business Administration \& Social Sciences, Mohammad Ali Jinnah University, Karachi, Pakistan.

*** Nargis, M.Phil. Scholar, Department of Economics, University of Karachi
} 
The following block diagram explains the flow of investment:

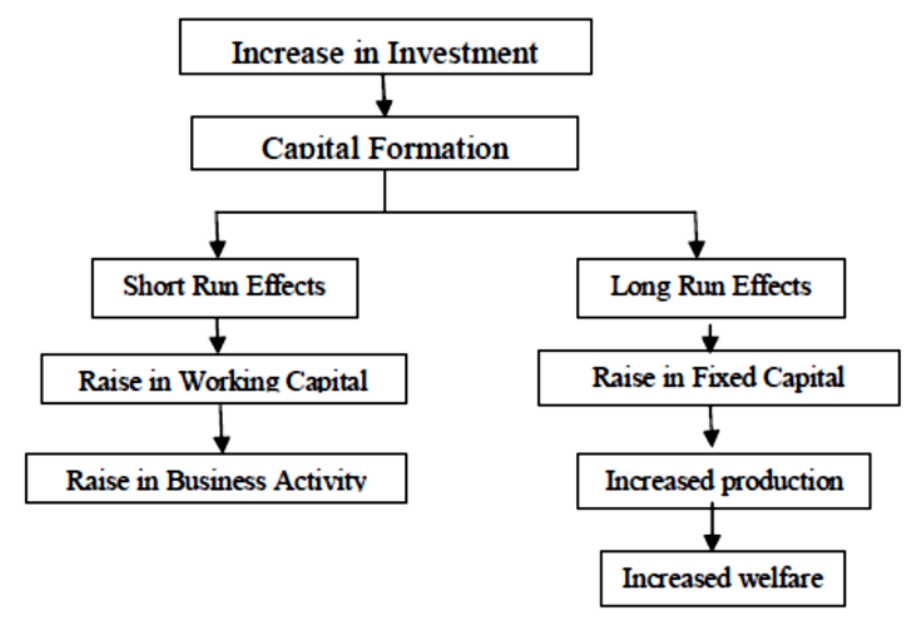

Source: Tabulated by Author

Investment in different sectors, ultimately, raise the capital formulation which is further analyzed in terms of its short and long run effects. In short run, increase in capital is associated with the increase in working capital that fosters the business activity. However, the long run effect implies an increase in fixed capital. Fixed capital is used to accelerate the production that later causes increase in the welfare of the economy. The rising trend in interest rate surges the cost of capital for the business sector that is invested in the working and business fixed capital. It also increases the cost of holding inventories.

The overall real economic growth of Pakistan on average was about 5.4 percent in the decade of 1970s and rose to 6.4 percent in the era of 1980s. The period of 1990s showed the average growth rate of only 5 percent at the time when technological changes were booming the world economy. The rate remained under 5 percent in the decade of 2000s and decelerated to the rate 3.7 in the last six fiscal years (2009-10 to 2014-15). ${ }^{1}$

\footnotetext{
${ }^{1}$ Facts and data in this section taken from Handbook of Statistics on Pakistan Economy 2015 published by State Bank of Pakistan. Analysis by authors.
} 


\section{Figure-1: Plot of Total investment Percent of GDP}

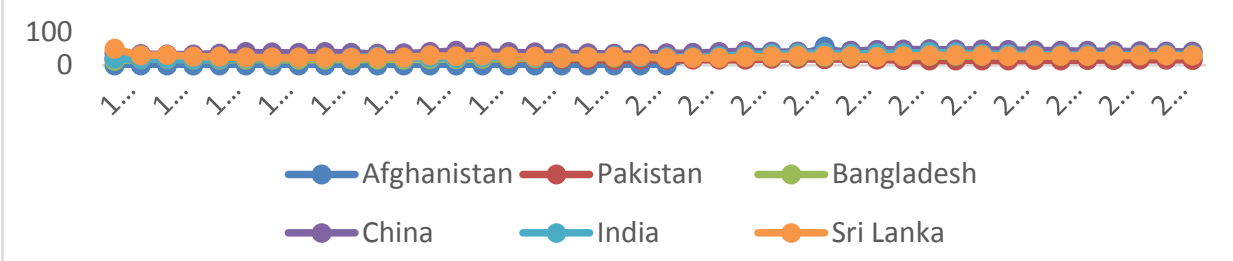

Source: Haver Analytics/World Economic Outlook database

This declining trend in the growth of the economy can be attributed to the reduction in the overall investment level in Pakistan. From 1973 to 1979 the gross total investment as percentage of GDP was 16.9 and it raised to 19.15 percent in the period of $1980 \mathrm{~s}$. The rate took a hike in the decade of 1990s and grasped the average of 20.5 percent. However, it declined slightly by one percent in 2000 s and now it is 15.77 percent of GDP for the year 2015. The decline in total investment portrays the instable condition of investment in Pakistan that affects the potential growth of the economy. Consequently, the economy is unable to match the growth of other Asian Countries as the total investment to GDP ratio of Pakistan is very low. Pakistan is at 151th rank for investment rate among 175 economies in 2015. Even the investment is well below from its neighboring economies like Bangladesh (40\%), India (32\%), and Sri Lanka (36\%). ${ }^{2}$

The objective of this research is to consider the association among the variables in the model for the time span of 1973 to 2015 in the context of Pakistan. This may help to test the traditional economic theory of investment and interest rate. Contrary to our previous study we have selected this time period due to structural changes after 1973. Initially we checked the stationary of the data, through employing various unit root tests, and latterly analyzed the long and short run association among the variables of interest.

The study is further categorized in five sections. The next section critically evaluates the literature by incorporating various national and international work on this topic. Section 3 moots the methodology. Section 4 discusses empirical results to analyze the nexus between interest rate and investment. Section 5 concludes with some practically possible recommendations.

\section{Literature Review}

The nexus between interest rate and investment has being discussed by innumerable research work. These studies were empirical in nature and drew various inferences regarding the association between the rate of interest and investment.

According to the Baillie and McMahon (1981) ${ }^{3}$ used Granger Causality tests as well as Box-Jenkins models to see the impact of three interest rate shocks, and GDP for Federal Republic of Germany during the time period 1960 to 1978 on investment. Results

\footnotetext{
${ }^{2}$ www.sbp.org.pk/publications/staff-notes/SavingInvestmentStaffNote-Jan-16.pdf

${ }^{3}$ Baillie, Richard T., and P. C. McMahon. Interest rates and investment in West Germany. (Empirical Economics 6, no. 1 1981): 1-9.
} 
indicated that the impact of rate of interest on investment is diverse in two different time periods because of the diverse policy. They determined that investment is inelastic regarding short-term nominal rate of interest and same results found in case of the real interest rate. Nevertheless, they also found long-term nominal interest rates influence investment. This result remains same even after government shifted their policies about regulating money supply instead of controlling interest rates.

Lanyi and Saracoglu ${ }^{4}$ concluded that the correlation between investment and interest rate was a positive. They gathered the data of 21 developing countries, span from 1971 to 1980, and examine the real financial assets and the growth of real interest rates. They ended up with a direct association between the growth of real financial assets and real interest rates.

However, Ingersoll and Ross ${ }^{5}$ replace discount rate by stochastic interest rate and found that the interest rate uncertainty had adverse impacts on investment.

Joshua and Delano ${ }^{6}$ conducted a study on the causal factors of private investment in Less Developing Countries on 23 less developing countries for the span 1975 to 1985 . They confirm the result that the real interest rate is inversely related to investment.

Alvareand and Koskef ${ }^{7}$ observed the irretrievable investment with changes in interest rates. This modification in interest rate had direct and sometimes indirect effect on investment demand.

James and Larsen ${ }^{8}$ studied the effect of rates of lending on real estate investment holding period return in the case of United State, they found that real estate investment has inversely related to interest rates.

Andrea Beccarini ${ }^{9}$ used the discount factor to exemplify the investment and the Generalized Movement Method was employed to examine the association between interest rate and investment in an ambiguous environment, the outcome indicates that the correlation was positive between interest rate and investment. And the higher instability of the interest rate, the higher the positive correlation would be.

Bader and Malawi ${ }^{10}$ investigated the effect of rate of interest on the investment in case of Jordan, A cointegration analysis. The results confirmed economic theory and various

\footnotetext{
${ }^{4}$ Lanyi, Anthony, and Rüsdü Saracoglu. The importance of interest rates in developing economies. (Finance and Development 20, no. 2 1983): 20.

${ }^{5}$ Ingersoll Jr, Jonathan E., and Stephen A. Ross. Waiting to invest: Investment and uncertainty. (Journal of Business 1992): 1-29.

${ }^{6}$ Greene, Joshua, and Delano Villanueva. Determinants of private investment in LDCs. (Finance and Development 27, no. 4 1990): 40.

${ }^{7}$ Alvarez, Luis Hernan Radomiro, and Erkki Koskela. Irreversible investment under interest rate variability: new results. (Finland: Bank of Finland Discussion Papers 2003): 1-27

${ }^{8}$ Larsen, James E. The impact of loan rates on direct real estate investment holding period return. (Financial Services Review 13, no. 2 2004): 111.

${ }^{9}$ Beccarini, Andrea. Investment sensitivity to interest rates in an uncertain context: is a positive relationship possible?.(Economic Change and Restructuring 40, no. 3 2007): 223-234.

${ }^{10}$ Bader, Majed, and Ahmad Ibrahim Malawi. The impact of interest rate on investment in Jordan: a cointegration analysis.(Journal of King Abdulaziz University: Economics and Administration 24, no. 1 2010): 199-209.
} 
studies that the real rate of interest and the investment are negatively related; by contrast, the income and investment are positively associated.

Luis H.R Alvarez (2010) used the diffusion model of short term interest rates and exhibited that ambiguity in interest rates may limit enterprise scale as well as the investment.

Whuyan et al. (2015) ${ }^{11}$ examined the relationship between investment and interest rate in Jiangsu Province of China. This province is the largest according to investment. Johansen Co-integration test is employed for long run nexus. Whereas, for short run association VECM (vector error correction model) is employed, over the span from 2003 to 2012. The empirical outcomes indicated that investment and interest rate has long-term association. The association is negative in the long run however the relationship is positive in the short run. It can be concluded from the study that reducing the rate promoted investment. However concurrently, it is detected that the impact of interest rate on the investment is quite weak. Apart from the rate of interest, market size, economic development level, investment environmental and preferential policies also impact investment.

Few studies have centered on the economy of Pakistan in examining the causal factors of investment.

Sakr $(1993)^{12}$ has studied the determining factors of private investment in case of Pakistan and determined that the growth rate of GDP, growth of the private sector loans and public investment are significant factors that determine private investment in case of Pakistan.

Hyder and Ahmed (2003) ${ }^{13}$ looked into the reasons that why private investment has reduced and how it can be fixed in case of Pakistan. They explored that increase in real interest dampens the investment level.

Ahmed (2001) ${ }^{14}$ concluded that production, Public Sector Development Plan (PSDP) and interest rate influence net investment. He also established that the PSDP and interest rate are the most important factors of private investment in case of Pakistan.

Muhammad et al. $(2013)^{15}$ analyzed the impact of real interest rate and income on investment in case of Pakistan. Johansen cointegration test is employed to test the cointegration among the variables for the span of 1964 to 2012. The results confirmed the economic theory that investment has negative relationship with real rate of interest in Pakistan.

\footnotetext{
${ }^{11}$ Wuhan, Li Suyuan, and Adnan Khurshid. The effect of interest rate on investment; Empirical evidence of Jiangsu Province, China. (Journal of International Studies Vol 8, no. 1 2015): 81-90.

${ }^{12}$ Sakr, Khaled. Determinants of private investment in Pakistan. (IMF Working Paper 1993): 1-20

${ }^{13}$ Hyder, Kalim, and Qazi Masood Ahmed. Why private investment in Pakistan has collapsed and how it can be restored. (The Lahore Journal of Economics, Vol.9, No.12003): 107-128.

${ }^{14}$ Ahmed, Qazi Masood. The Influence of Tax Expenditures on Non-residential Investment,(Journal of development economics 65, 2001): 477-489.

${ }^{15}$ Muhammad, D. Sulaiman, Rasool Lakhan, Saba Zafar, and Muhammad Noman. Rate of Interest and its Impact on Investment to the Extent of Pakistan. (Pakistan Journal of Commerce and Social Sciences 7, no. 1 2013): 91-99.
} 
Jamil and Muhammad (2015) ${ }^{16}$ investigated the impact of rate of interest on private investment as well as the economic growth of Pakistan. They used time series data span from 1980 to 2010. They as well used structural equation model to discover the associations among the said variables in the model. The outcomes showed that labor force, government expenditures, and private investment have positive and significant impact on GDP however, FDI has statistically significant and negative association with GDP. There as well exists a distinctive long term association between the growth of the economy and its factors, including rate of interest. The outcomes suggest that the behavior of the rate of interest is significant for the growth of the economy considering the associations between the rate of interest and investment and the growth of the economy.

Afta et al. (2016) ${ }^{17}$ explored the long run as well as short run impact of rate of interest on the private sector credit in case of Pakistan during 1975 to 2011. ADF and PP test is used to analyze the Stationary of data. This article used ARDL model for the aim of examining long run as well as short run association. The outcomes confirmed the economic theory that there is significant negative association between rate of interest and private sector credit in the long term, as well as also in the short term. The outcomes moreover showed significant positive association between inflation and private sector credit in the long run as well as short run. But, exchange rate was detected to have no impact on the private sector credit.

On the basis of literature review above we can say that a persistently poor performance of the economic growth that also lower the investment levels is the crucial problem that unfavorably impact the economy of Pakistan for the last decade. An insightful examination of the key factors of investment that is rate of interest and income is rationally useful for Pakistan.

\footnotetext{
${ }^{16}$ Jamil, Naveed Iqbal Muhammad Farooq. Interest Rates, Government and Private Investments and Pakistan Economy: An Analysis of Three Decades. (International Journal of African and Asian Studies Vol.14, 2015): 161-166

${ }^{17}$ Afta, Nadeem, Khalil Jebran, Irfan Ullah, and Muhammad Awais. Impact of Interest Rate on Private Sector Credit; Evidence from Pakistan." (Jinnah Business Review, Vol.4, No.1, 2016): 47-52.
} 


\section{Methodology}

The following functional form of investment function is used for analysis:

$$
\operatorname{Inv}=f\left(\begin{array}{cc}
R & Y \\
(-)^{\prime} & (+)
\end{array}\right)
$$

Gross total investment is employed as proxy variable for the investment level (Inv). Gross Domestic Product at factor cost is employed as proxy variable for the income level $(\mathrm{Y})$, which has expected positive association with investment. Annual Call Money Rate is used as the proxy of rate of interest $(\mathrm{R})$ which has expected negative association with investment.

The Data is taken from the Handbook of Statistics of Pakistan $2015^{18}$ by the State Bank of Pakistan for the time period of 1973 to 2015.

\section{The Phillips-Perron (PP) Test}

The Stationarity of variables is checked by applying Unit Root test of Phillips and Perron test (1988). ${ }^{19}$ Phillips and Perron $(1988)^{20}$ suggested a different method to test the unit root of a series and also tested serial correlation. The PP test estimates the non-ADF test equation which is as follow,

$$
\Delta y_{t}=\alpha y_{t-1}+x_{t}^{\prime} \delta+\epsilon_{t}
$$

The test modifies the t-ratio of the $\alpha$ coefficient so that the serial correlation does not affect the asymptotic distribution of the test statistic. The PP method is based on the following statistic:

$$
t_{\alpha}=t_{\alpha}\left(\frac{\gamma_{0}}{f_{0}}\right)^{1 / 2}-\frac{T\left(f_{0}-\gamma_{0}\right)(s e(\hat{\alpha}))}{2 f_{0}^{1 / 2} s}
$$

where $\hat{\alpha}$ is the estimate, and $t_{\alpha}$ is the t-ratio of $\alpha$, se $(\hat{\alpha})$ is coefficient standard error, and $\mathrm{s}$ is the standard error of the test regression. In the above equation, $\gamma_{0}$ is a consistent estimator of the error variance while the remaining term, $f_{0}$ is an estimator of the residual spectrum at frequency of zero. The asymptotic distribution of the PP test modifies t-ratio the same way as that of the ADF statistic.

\footnotetext{
${ }^{18}$ www.sbp.org.pk/departments/stats/PakEconomy_HandBook/index.htm

${ }^{19}$ Phillips, Peter CB, and Pierre Perron. Testing for a unit root in time series regression. (Biometrika 75, no. 2 1988): 335-346.

${ }^{20}$ Ibid
} 


\section{Autoregressive Distributed Lag (ARDL) Model}

ARDL model is standard least squares regression that includes lags of both the dependent variable and explanatory variables as regressors (Greene, 2008). ${ }^{21}$ The ARDL model by Pesaran and Shin $(1998)^{22}$ and Pesaran, Shin and Smith $(2001)^{23}$ has been used in econometrics. However, it has gained high acceptance in recent years as it examines the cointegration between variables.

\section{ARDL Specification}

ARDL model is a linear time series model in which both the dependent and independent variables are not only linked but are also distributed across their (lagged) values. If $y_{t}$ is the dependent variable and $x_{1}, \ldots \ldots \ldots, x_{k}$ are $k$ explanatory variables, a general ARDL $q, q_{1}, \ldots \ldots ., q_{k}$ model is given by:

$$
y_{t}=\alpha_{0}+\alpha_{1} t+\sum_{i=1}^{p} \varphi_{i} y_{t-i}+\sum_{j=1}^{k} \sum_{l_{j}=0}^{q_{j}} \beta_{j, l_{i}} x_{j, t-l_{j}}+\epsilon_{t}
$$

Where $\epsilon_{t}$ is the usual innovation, $\alpha_{0}$ is a constant term, and $\alpha_{1}, \varphi_{i}$, and $\beta_{j, l_{i}}$ are respectively the coefficients associated with the linear trend, lags of $y_{t}$, and lags of the $\mathrm{k}$ regressors $x_{j, t}$ for $\mathrm{j}=1, \ldots, \mathrm{k}$.

The above formulation represents three alternative methods for parameter estimation. The first method is typically used for inter-temporal dynamic estimation while the second one is for the long run post-estimation. The third method reduces the above equation to the conditional error correction. This method is exemplified in the Pesaran, Shin and Smith $(2001)^{24}$ bounds test.

Conventionally, the cointegration tests of Engle-Granger (1987) ${ }^{25}$, Phillips and Ouliaris $(1990)^{26}$, Park $(1990)^{27}$, or Johansen $(1991)^{28}$, Johansen $(1995)^{29}$, require all variables to be stationary at I(1) in the VAR. This property requires a pre-testing for the presence of a unit root in each of the variables under consideration and this creates the problem of

\footnotetext{
${ }^{21}$ Greene, William H. The econometric approach to efficiency analysis. (The measurement of productive efficiency and productivity growth 1 2008): 92-250.

${ }^{22}$ Pesaran, M. Hashem, and Yongcheol Shin. An autoregressive distributed-lag modelling approach to cointegration analysis. (Econometric Society Monographs 31 1998): 371-413.

${ }^{23}$ Pesaran, M. Hashem, Yongcheol Shin, and Richard J. Smith. Bounds testing approaches to the analysis of level relationships. (Journal of applied econometrics 16, no. 3 2001): 289-326.

${ }^{24}$ ibid

${ }^{25}$ Engle, Robert F., and Clive WJ Granger. Co-integration and error correction: representation, estimation, and testing. (Econometrica: journal of the Econometric Society 1987): 251-276.

${ }^{26}$ Phillips, Peter CB, and Sam Ouliaris. Asymptotic properties of residual based tests for cointegration. (Econometrica: Journal of the Econometric Society 1990): 165-193.

${ }^{27}$ Park, Joon Y. Testing for unit roots and cointegration by variable addition. (Advances in econometrics 8, no. 2 1990): 107-133.

${ }^{28}$ Johansen, Søren. Estimation and hypothesis testing of cointegration vectors in Gaussian vector autoregressive models. (Econometrica: Journal of the Econometric Society 1991): 1551-1580.

${ }^{29}$ Soren, Johansen. Likelihood-based inference in cointegrated vector autoregressive models. (OUP Catalogue 1995).
} 
misspecification. In contrast, Pesaran, Shin and Smith $(2001)^{30}$ proposed a robust test for cointegration. It explains that whether variables of interest are $\mathrm{I}(0), \mathrm{I}(1)$, or mutually cointegrated. Incidentally, Pesaran, Shin and Smith $(2001)^{31}$ discussed a bounds test for cointegration to test the significance of cointegrated parameters. In other words, the test is a standard F or Wald test for the following null and alternative hypotheses:

$$
\begin{aligned}
& H_{0}:\left(\varphi(1) \cap\left\{\beta_{j}(1)\right\}_{j=1}^{k}\right)=0 \\
& H_{A}:\left(\varphi(1) \cap\left\{\beta_{j}(1)\right\}_{j=1}^{k}\right) \neq 0
\end{aligned}
$$

Once the test statistic is computed, it is compared to the two asymptotic critical values corresponding to polar cases of all variables. These variables are either $\mathrm{I}(0)$ or $\mathrm{I}(1)$. When the test statistic is below the lower critical value, one fails to reject the null and concludes that cointegration doesn't exist. In contrast, when the test statistic is above the upper critical value, one rejects the null and concludes that there is cointegration. However, knowledge of the cointegrating rank is not required.

Alternatively, if the test statistic falls between the lower and upper critical values, it is inconclusive, and knowledge of the cointegrating rank is required to proceed further.

\section{Error Correction Model (ECM)}

ECM fits in the class of multivariate models and it is employed for time series data where the cointegrated variables show random trend and thus presents better long run association or cointegration. ECM is used for calculating both short and long run impacts of one series on another. The model deals with the concept that last-period deviates from its long-run equilibrium due to the shock or the error, which affects its short-term dynamics. Therefore, ECM instantly calculates the pace at which a regress and variable brings back to long run equilibrium after a shocks in other regressor variables.

\section{Empirical Results and Analysis}

To evaluate the order of integration of the variables PP Unit Root Test is used.

Table 1

Philips-Perron Unit Root Test

\begin{tabular}{|l|c|c|c|c|}
\hline Variables & $\begin{array}{c}\text { Calculated } \\
\text { value }\end{array}$ & $\begin{array}{c}\mathbf{5 \%} \text { Tabulated } \\
\text { value }\end{array}$ & $\begin{array}{c}\text { 10\% Tabulated } \\
\text { value }\end{array}$ & Prob.** \\
\hline $\mathrm{INV}(4)$ & 3.094215 & -3.52079 & -3.19128 & 1.0000 \\
\hline$\Delta(\mathrm{INV})(2)$ & -3.42625 & -3.52362 & -3.1929 & $0.0618^{* * *}$ \\
\hline$\Delta(\mathrm{INV}, 2)(2)$ & -12.6939 & -3.52661 & -3.19461 & 0.0000 \\
\hline $\mathrm{R}(2)$ & -3.05008 & -2.93316 & -2.60487 & $0.0384^{* *}$ \\
\hline$\Delta(\mathrm{R})(1)$ & -6.00942 & -2.935 & -2.60584 & 0.0000 \\
\hline$\Delta(\mathrm{R}, 2)(12)$ & -17.332 & -2.93694 & -2.60686 & 0.0000 \\
\hline
\end{tabular}

${ }^{30}$ Pesaran, M. Hashem, Yongcheol Shin, and Richard J. Smith. Bounds testing approaches to the analysis of level relationships. (Journal of applied econometrics 16, no. 3 2001): 289-326.

${ }^{31}$ Ibid 


\begin{tabular}{|l|c|c|c|c|}
\hline $\mathrm{Y}(4)$ & 4.731493 & -3.520787 & -3.191277 & 1.0000 \\
\hline$\Delta(\mathrm{Y})(5)$ & -3.465816 & -3.523623 & -3.192902 & $0.0567^{* * *}$ \\
\hline$\Delta(\mathrm{Y}, 2)(3)$ & -14.21641 & -3.526609 & -3.194611 & 0.0000 \\
\hline
\end{tabular}

Source: Summarized and Calculated by Authors

Note: *MacKinnon (1996) one-sided p-values., $* *=5 \%$ significance level and $* * *=10 \%$ significance level. [Y: The Level form of the variable $\mathrm{Y}][\Delta(\mathrm{Y})$ : The first change of the variable $\mathrm{Y}][\Delta(\mathrm{Y}, 2)$ : The second difference of the variable $\mathrm{Y}]$

Above table 1 represent the result of the Philips-Perron Unit Root Test for all the selected variables. With the help of graphical analysis, it is observed investment and income have trend and intercept only interest rate has only intercept so Philips-Perron Unit Root Test estimate accordingly for all the three variables. Investment and income are stationary at the first difference at the 10 percent level of significance. Interest rate is stationary at levels. All the variables are integrated at level and order one, i.e., is I(0) \& I(1), so it is justified to use Autoregressive Distributed Lag model F-statistic at the next stage to find whether the long run association among the chosen variables exists or not for the span of 1973-2015 in case of Pakistan. The result of the above mentioned Autoregressive Distributed Lag model is reported in table no. 2.

Table 2

The ARDL Cointegration Analysis

\begin{tabular}{|c|c|c|}
\hline Estimated Model & \multicolumn{2}{|l|}{$\operatorname{Inv}=f(R, Y)$} \\
\hline $\begin{array}{l}\text { Optimal lags } \\
\text { structure }\end{array}$ & \multicolumn{2}{|l|}{$(3,2,1)$} \\
\hline F-statistics & \multicolumn{2}{|l|}{$7.108539 *$} \\
\hline \multirow{2}{*}{ Significant level } & \multicolumn{2}{|l|}{ Critical values $(T=40)^{\#}$} \\
\hline & Lower bounds, $I(0)$ & Upper bounds, $I(1)$ \\
\hline $1 \%$ & 4.13 & 5 \\
\hline $2.5 \%$ & 3.55 & 4.38 \\
\hline $5 \%$ & 3.1 & 3.87 \\
\hline $10 \%$ & 2.63 & 3.35 \\
\hline \multicolumn{2}{|c|}{$R^{2} 0.998083, A d j-R^{2} 0.997588$, F-statistics } & $2017.632^{* * *}, \mathrm{DW}$ Test 2.014121 \\
\hline \multicolumn{3}{|c|}{$\begin{array}{l}\chi^{2} \text { NORMAL } 3.19(0.202) \chi^{2} \text { SERIAL } 1.82(0.177) \chi^{2} \text { ARCH } 1.22(0.27) \\
\chi^{2} \text { WHITE } 9.41(0.31)\end{array}$} \\
\hline
\end{tabular}

Source: Summarized and Calculated by Authors

The outcomes of the ARDL Cointegration Analysis specify that the calculated F-statistic which is 7.108539 is greater than upper critical bounds at the $1 \%$ level of significance once we used income and Interest rate are employed as explanatory variables. The outcomes confirm the presence of long run association or cointegration among the selected variables. This shows that there is a long run relationship between investments, income and interest rate for the span of 1973-2015 in case of Pakistan. This confirms the economic theory of investment. A description of how the interest rate impacts the investment in the economic system. Normally, higher rate of interest shrink investment, 
since higher rate of interest increase the borrowing cost and necessitate investment to have a higher return to be lucrative.

Additionally, this ARDL model bounds testing approach has fulfilled the assumptions of the Classical Linear Regression Model, for example the error term of this model follow a normal distribution. The ARDL model does not suffer from serial correlation between the error term and variables. There is no indication of autoregressive conditional heteroskedasticity or ARCH test and similar conclusion can be depicted for white heteroskedasticity test.

Table 3

Estimated Long Run Coefficients using the ARDL Approach

\begin{tabular}{|l|r|r|r|r|}
\hline Variable & \multicolumn{1}{|l|}{ Coefficient } & \multicolumn{1}{l|}{ Std. Error } & \multicolumn{1}{l|}{ t-Statistic } & \multicolumn{1}{l|}{ Prob. } \\
\hline $\mathbf{R}$ & -21986.21305 & 10469.17566 & -2.10009 & 0.0440 \\
\hline $\mathbf{Y}$ & 0.114528 & 0.012333 & 9.286608 & 0.0000 \\
\hline $\mathbf{C}$ & 230062.6942 & 95568.14055 & 2.407316 & 0.0222 \\
\hline
\end{tabular}

Source: Summarized and Tabulated by Authors

Table 3 explains that all selected variables have long run association. If there is a $1 \%$ increase in the interest rate the investments decrease by 21986.21305 million rupees and if income cost increase by 1 million the investments increase by 0.114528 million rupees.

Cointegration Equation $=\mathrm{INV}-(0.1145 * \mathrm{Y}-21986.2130 * \mathrm{R}+230062.6942)$

Above define equation explains the long run equilibrium association between the investments, interest rate and income. The sign of the coefficient is according to the economic theory. Investment has strong and positive association with income cost, while investment has strong and an inverse association with interest rate. All coefficients are significant at the $5 \%$ level.

Country like Pakistan needs investment to grow at a higher rate. These results are in line with the economic theory; if monetary authority controls the rate of interest it will be encouraging for the economy of Pakistan. It will also help in China, Pakistan Economic Corridor (CPEC) project. 
Table 4

Error Correction Representation for the Selected ARDL Model

\begin{tabular}{|l|l|l|l|l|}
\hline Variable & Coefficient & Std. Error & t-Statistic & Prob. \\
\hline $\mathrm{D}(\mathrm{INV}(-1))$ & 0.744082 & 0.119328 & 6.235594 & 0.0000 \\
\hline $\mathrm{D}(\mathrm{INV}(-2))$ & 0.46634 & 0.160062 & 2.913489 & 0.0066 \\
\hline $\mathrm{D}(\mathrm{Y})$ & 0.111931 & 0.026969 & 4.150364 & 0.0002 \\
\hline $\mathrm{D}(\mathrm{Y}(-1))$ & 0.115911 & 0.025149 & 4.608994 & 0.0001 \\
\hline $\mathrm{D}(\mathrm{R})$ & 7783.81813 & 5001.83124 & 1.556194 & 0.1298 \\
\hline $\mathrm{ECT}_{\mathrm{t}-1}$ & -0.566316 & 0.10141 & -5.58443 & 0.0000 \\
\hline
\end{tabular}

Source: Summarized and Tabulated by Authors

Error Correction Representation for the Selected ARDL Model clarify that the $\mathrm{ECT}_{\mathrm{t}-1}$ is negative and significant at the $1 \%$ level. Error correction term explains model will converge to the equilibrium with time. The value of the error correction term is 0.566316 which shows that the disequilibrium is corrected $56.63 \%$ in one year and model will achieve equilibrium 1.77 years. The short run analysis shows that interest rate also impact the investment in case of Pakistan.

Figure-2

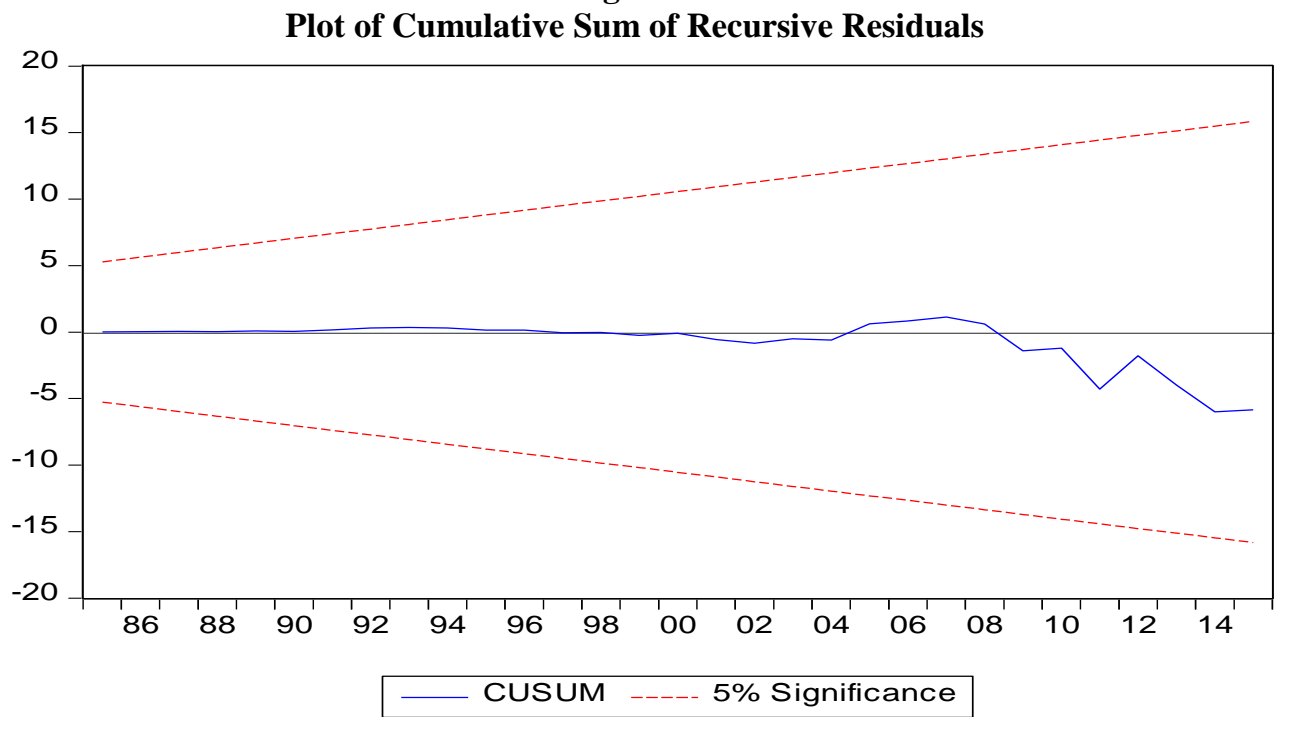

Source: Summarized and Tabulated by Authors from Eviews

The result of CUSUM is reported in Figures 1. The plot of the CUSUM test does not cross upper or lower critical limit so it can be concluded that this model is stable. 


\section{Conclusions and Recommendations}

The purpose of this study is to elucidate the impact of income and the rate of interest on the investment to the extent of Pakistan. This study covers the span from 1973 to 2015. The proxy used for the study are call money rate for interest rate, GDP at factor cost for income, and gross total investment for investment. Additionally, PP Unit Root Test is used for checking the stationary of the data. Autoregressive Distributed Lag or (ARDL) Model is used to check the long run dynamics and ECM is used for short run analysis.

According to the Economic theory that there is an inverse association between investment and interest rate as well as there is a positive association between investment and income.

The analysis performed above confirmed that investment and Income cost are stationary at the first difference at the $10 \%$ level of significance. Interest rate is stationary at levels. All the variables are integrated at level and order one, i.e. is $\mathrm{I}(0) \& \mathrm{I}(1)$, so it was justified to use Autoregressive Distributed Lag Model.

The results of the Autoregressive Distributed Lag Model Cointegration Analysis determine that the estimated F-statistic which is 7.108539 is greater than upper critical bounds at the $1 \%$ level of significance. The results endorse the existence of cointegration among the selected variables for the span of 1973-2015 in case of Pakistan.

The short run dynamics explains that the ECM model will converge to the equilibrium with time because ECT is negative and statistically significant at the $1 \%$ level. The value of the error correction term is corrected $56.63 \%$ in one year and model will achieve equilibrium in less than two years.

A consistently declining in the policy rate encourages investment and economic growth in Pakistan that positively affect the economy of Pakistan for the last few years. ${ }^{32} \mathrm{~A}$ complete and comprehensive analysis of the determining factors of private and public investment in different sectors of the economy of Pakistan is fairly encouraging in scheming there vitalization plan for the economy of Pakistan. Not only policy rate, however different factors like for example controlled law and order situation, war against terrorism, stable democratic government and other reasons to create a favorable environment for investment. CPEC is a milestone is this regard. To attract investment in Pakistan institution has to keep control the interest rate.

\footnotetext{
${ }^{32}$ https://tribune.com.pk/story/437339/monetary-policy-why-the-state-bank-will-keep-lowering-interest-rates/
} 
APPENDICES

Annexure 1: Data used in the Study

\begin{tabular}{|c|c|c|c|}
\hline Years & GTInv & GDPFC & CMR \\
\hline 1973 & 8647 & 61877 & 5.68 \\
\hline 1974 & 11614 & 82307 & 8.48 \\
\hline 1975 & 18218 & 104704 & 10.63 \\
\hline 1976 & 22769 & 122728 & 9.4 \\
\hline 1977 & 27421 & 141462 & 10.03 \\
\hline 1978 & 29960 & 171979 & 11.2 \\
\hline 1979 & 33355 & 192377 & 8.99 \\
\hline 1980 & 41375 & 228537 & 8.97 \\
\hline 1981 & 52208 & 270523 & 8.61 \\
\hline 1982 & 62447 & 317502 & 9.86 \\
\hline 1983 & 68462 & 367807 & 8.69 \\
\hline 1984 & 76701 & 413944 & 8.1 \\
\hline 1985 & 86525 & 463375 & 9.13 \\
\hline 1986 & 96545 & 507678 & 7.26 \\
\hline 1987 & 109540 & 551809 & 6.26 \\
\hline 1988 & 121666 & 630120 & 6.27 \\
\hline 1989 & 145570 & 711143 & 6.34 \\
\hline 1990 & 162076 & 796751 & 6.77 \\
\hline 1991 & 193446 & 932282 & 7.12 \\
\hline 1992 & 244060 & 1090480 & 7.36 \\
\hline 1993 & 277744 & 1210089 & 9.81 \\
\hline 1994 & 305477 & 1416846 & 9.18 \\
\hline 1995 & 346045 & 1686020 & 10.33 \\
\hline 1996 & 402762 & 1922755 & 11.16 \\
\hline 1997 & 435134 & 2207230 & 12.97 \\
\hline 1998 & 474245 & 2456520 & 12.23 \\
\hline 1999 & 457357 & 2710396 & 7.84 \\
\hline 2000 & 659110 & 3514064 & 8.52 \\
\hline 2001 & 715525 & 3868762 & 8.96 \\
\hline 2002 & 738373 & 4169832 & 6.74 \\
\hline 2003 & 817062 & 4686030 & 4.23 \\
\hline 2004 & 935085 & 5375005 & 1.86 \\
\hline 2005 & 1240240 & 6257029 & 4.34 \\
\hline
\end{tabular}




\begin{tabular}{|r|r|r|r|}
\hline 2006 & 1687809 & 7715777 & 10.5 \\
\hline 2007 & 1953388 & 8735766 & 10.27 \\
\hline 2008 & 2258628 & 10355255 & 10.67 \\
\hline 2009 & 2414749 & 12542265 & 13.38 \\
\hline 2010 & 2431664 & 14248547 & 10.8 \\
\hline 2011 & 2581000 & 17647553 & 13.1 \\
\hline 2012 & 3022000 & 19361511 & 13.1 \\
\hline 2013 & 3348000 & 21496680 & 9.5 \\
\hline 2014 & 3756000 & 23903982 & 9 \\
\hline 2015 & 4140000 & 25821943 & 7.4 \\
\hline
\end{tabular}




\section{Annexure 2: Table generated by Eviews Software}

Phillips-Perron unit root Test

Null Hypothesis: GTINV has a unit root

Exogenous: Constant, Linear Trend

Bandwidth: 4 (Newey-West automatic) using Bartlett kernel

\begin{tabular}{lccc}
\hline \hline & & Adj. t-Stat & Prob.* $^{*}$ \\
\hline \hline Phillips-Perron test statistic & & 3.094215 & 1.0000 \\
\hline Test critical values: & 1\% level & -4.192337 & \\
& $5 \%$ level & -3.520787 & \\
& $10 \%$ level & -3.191277 & \\
\hline \hline
\end{tabular}

*MacKinnon (1996) one-sided p-values.

Residual variance (no correction)

$6.57 \mathrm{E}+09$

HAC corrected variance (Bartlett kernel)

Phillips-Perron Test Equation

Dependent Variable: D(GTINV)

Method: Least Squares

Date: 07/20/17 Time: 11:17

Sample (adjusted): 19742015

Included observations: 42 after adjustments

\begin{tabular}{lrcrr}
\hline \hline \multicolumn{1}{c}{ Variable } & Coefficient & Std. Error & t-Statistic & Prob. \\
\hline \hline \multicolumn{1}{c}{ GTINV(-1) } & 0.077072 & 0.023750 & 3.245147 & 0.0024 \\
\multicolumn{1}{c}{ @TREND("1973") } & -24072.95 & 32152.63 & -0.748709 & 0.4585 \\
\multicolumn{1}{c}{2889.311} & 2022.652 & 1.428476 & 0.1611 \\
\hline \hline R-squared & 0.651417 & Mean dependent var & 98365.55 \\
Adjusted R-squared & 0.633541 & S.D. dependent var & 138982.5 \\
S.E. of regression & 84134.28 & Akaike info criterion & 25.58696 \\
Sum squared resid & $2.76 \mathrm{E}+11$ & Schwarz criterion & 25.71108 \\
Log likelihood & -534.3263 & Hannan-Quinn criter. & 25.63246 \\
F-statistic & 36.44076 & Durbin-Watson stat & 1.287179 \\
Prob(F-statistic) & 0.000000 & & \\
\hline \hline
\end{tabular}

Null Hypothesis: D(GTINV) has a unit root

Exogenous: Constant, Linear Trend

Bandwidth: 2 (Newey-West automatic) using Bartlett kernel

\begin{tabular}{llll}
\hline \hline & & Adj. t-Stat & Prob. $^{*}$ \\
\hline \hline Phillips-Perron test statistic & & -3.426251 & 0.0618 \\
\hline Test critical values: & $1 \%$ level & -4.198503 &
\end{tabular}



$5 \%$ level
$-3.523623$
$10 \%$ level

*MacKinnon (1996) one-sided p-values.

Residual variance (no correction)

$6.14 \mathrm{E}+09$

HAC corrected variance (Bartlett kernel)

$6.29 \mathrm{E}+09$

Phillips-Perron Test Equation

Dependent Variable: D(GTINV,2)

Method: Least Squares

Date: 07/20/17 Time: 11:17

Sample (adjusted): 19752015

Included observations: 41 after adjustments

\begin{tabular}{lrlrr}
\hline \hline \multicolumn{1}{c}{ Variable } & Coefficient & Std. Error & t-Statistic & Prob. \\
\hline \hline \multicolumn{1}{c}{ D(GTINV(-1)) } & -0.477155 & 0.140297 & -3.401038 & 0.0016 \\
\multicolumn{1}{c}{ @TREND("1973") } & -46875.38 & 29408.24 & -1.593954 & 0.1192 \\
\hline \hline R-squared & 4535.467 & 1558.571 & 2.910017 & 0.0060 \\
Adjusted R-squared & 0.239796 & Mean dependent var & 9293.488 \\
S.E. of regression & 0.199785 & S.D. dependent var & 91009.34 \\
Sum squared resid & 81412.17 & Akaike info criterion & 25.52279 \\
Log likelihood & $2.52 \mathrm{E}+11$ & Schwarz criterion & 25.64818 \\
F-statistic & -520.2173 & Hannan-Quinn criter. & 25.56845 \\
Prob(F-statistic) & 5.993280 & Durbin-Watson stat & 1.892174 \\
\hline \hline
\end{tabular}

Null Hypothesis: D(GTINV,2) has a unit root

Exogenous: Constant, Linear Trend

Bandwidth: 14 (Newey-West automatic) using Bartlett kernel

\begin{tabular}{lccc}
\hline \hline & & Adj. t-Stat & Prob.* \\
\hline \hline Phillips-Perron test statistic & & -12.69386 & 0.0000 \\
\hline Test critical values: & $1 \%$ level & -4.205004 & \\
& $5 \%$ level & -3.526609 & \\
& $10 \%$ level & -3.194611 & \\
\hline \hline
\end{tabular}

*MacKinnon (1996) one-sided p-values. 
Phillips-Perron Test Equation

Dependent Variable: D(GTINV,3)

Method: Least Squares

Date: 07/20/17 Time: 11:16

Sample (adjusted): 19762015

Included observations: 40 after adjustments

\begin{tabular}{lrlrr}
\hline \hline \multicolumn{1}{c}{ Variable } & Coefficient & Std. Error & t-Statistic & Prob. \\
\hline \hline \multicolumn{1}{c}{ D(GTINV(-1),2) } & -1.171825 & 0.162563 & -7.208431 & 0.0000 \\
C & -8592.739 & 32191.80 & -0.266923 & 0.7910 \\
\multicolumn{1}{c}{ @TREND("1973") } & 878.5561 & 1279.466 & 0.686659 & 0.4966 \\
\hline \hline R-squared & 0.584155 & Mean dependent var & -690.9250 \\
Adjusted R-squared & 0.561676 & S.D. dependent var & 140209.7 \\
S.E. of regression & 92827.28 & Akaike info criterion & 25.78691 \\
Sum squared resid & $3.19 \mathrm{E}+11$ & Schwarz criterion & 25.91357 \\
Log likelihood & -512.7381 & Hannan-Quinn criter. & 25.83271 \\
F-statistic & 25.98768 & Durbin-Watson stat & 2.061309 \\
Prob(F-statistic) & 0.000000 & & \\
\hline \hline
\end{tabular}

Null Hypothesis: CMR has a unit root

Exogenous: Constant

Bandwidth: 2 (Newey-West automatic) using Bartlett kernel

\begin{tabular}{lccc}
\hline \hline & & Adj. t-Stat & Prob.* \\
\hline \hline Phillips-Perron test statistic & & -3.050077 & 0.0384 \\
\hline Test critical values: & $1 \%$ level & -3.596616 & \\
& $5 \%$ level & -2.933158 & \\
& $10 \%$ level & -2.604867 & \\
\hline \hline
\end{tabular}

*MacKinnon (1996) one-sided p-values.

Residual variance (no correction)

Phillips-Perron Test Equation

Dependent Variable: $\mathrm{D}(\mathrm{CMR})$

Method: Least Squares

Date: 07/20/17 Time: 11:14

Sample (adjusted): 19742015

Included observations: 42 after adjustments

\begin{tabular}{lllll}
\hline \hline Variable & Coefficient & Std. Error & t-Statistic & Prob.
\end{tabular}




\begin{tabular}{|c|c|c|c|c|}
\hline $\begin{array}{c}\mathrm{CMR}(-1) \\
\mathrm{C}\end{array}$ & $\begin{array}{r}-0.325050 \\
2.932656\end{array}$ & $\begin{array}{l}0.113193 \\
1.045052\end{array}$ & $\begin{array}{r}-2.871632 \\
2.806229\end{array}$ & $\begin{array}{l}0.0065 \\
0.0077\end{array}$ \\
\hline R-squared & 0.170920 & Mean dependent va & & 0.040952 \\
\hline Adjusted R-squared & 0.150193 & S.D. dependent var & & 1.964748 \\
\hline S.E. of regression & 1.811202 & Akaike info criterion & & 4.072306 \\
\hline Sum squared resid & 131.2181 & Schwarz criterion & & 4.155052 \\
\hline Log likelihood & -83.51843 & Hannan-Quinn criter & & 4.102636 \\
\hline F-statistic & 8.246270 & Durbin-Watson stat & & 1.601718 \\
\hline Prob(F-statistic) & 0.006501 & & & \\
\hline
\end{tabular}

Null Hypothesis: $\mathrm{D}(\mathrm{CMR})$ has a unit root

Exogenous: Constant

Bandwidth: 1 (Newey-West automatic) using Bartlett kernel

\begin{tabular}{llll}
\hline \hline & & Adj. t-Stat & Prob. $^{*}$ \\
\hline \hline Phillips-Perron test statistic & & -6.009419 & 0.0000 \\
\hline Test critical values: & 1\% level & -3.600987 & \\
& $5 \%$ level & -2.935001 & \\
& $10 \%$ level & -2.605836 & \\
\hline \hline
\end{tabular}

*MacKinnon (1996) one-sided p-values.

Residual variance (no correction) 
Phillips-Perron Test Equation

Dependent Variable: $\mathrm{D}(\mathrm{CMR}, 2)$

Method: Least Squares

Date: 07/20/17 Time: 11:14

Sample (adjusted): 19752015

Included observations: 41 after adjustments

\begin{tabular}{lrlrr}
\hline \hline \multicolumn{1}{c}{ Variable } & Coefficient & \multicolumn{1}{c}{ Std. Error } & t-Statistic & Prob. \\
\hline \hline \multicolumn{1}{c}{ D(CMR(-1)) } & -0.945645 & 0.157272 & -6.012816 & 0.0000 \\
\multicolumn{1}{c}{ C } & -0.030743 & 0.306559 & -0.100284 & 0.9206 \\
\hline \hline R-squared & 0.481065 & Mean dependent var & -0.107317 \\
Adjusted R-squared & 0.467759 & S.D. dependent var & 2.688294 \\
S.E. of regression & 1.961240 & Akaike info criterion & 4.232582 \\
Sum squared resid & 150.0121 & Schwarz criterion & 4.316171 \\
Log likelihood & -84.76793 & Hannan-Quinn criter. & 4.263020 \\
F-statistic & 36.15396 & Durbin-Watson stat & 2.014426 \\
Prob(F-statistic) & 0.000000 & & \\
\hline \hline
\end{tabular}

Null Hypothesis: $\mathrm{D}(\mathrm{CMR}, 2)$ has a unit root

Exogenous: Constant

Bandwidth: 12 (Newey-West automatic) using Bartlett kernel

\begin{tabular}{llll}
\hline \hline & & Adj. t-Stat & Prob. \\
\hline \hline Phillips-Perron test statistic & & -17.33199 & 0.0000 \\
\hline Test critical values: & $1 \%$ level & -3.605593 & \\
& $5 \%$ level & -2.936942 & \\
& $10 \%$ level & -2.606857 & \\
\hline \hline
\end{tabular}

*MacKinnon (1996) one-sided p-values.

Residual variance (no correction)

Phillips-Perron Test Equation

Dependent Variable: $\mathrm{D}(\mathrm{CMR}, 3)$

Method: Least Squares

Date: 07/20/17 Time: 11:15

Sample (adjusted): 19762015

Included observations: 40 after adjustments

\begin{tabular}{ccccr}
\hline \hline Variable & Coefficient & Std. Error & t-Statistic & Prob. \\
\hline \hline $\mathrm{D}(\mathrm{CMR}(-1), 2)$ & -1.390959 & 0.149526 & -9.302427 & 0.0000
\end{tabular}




\begin{tabular}{|c|c|c|c|}
\hline C & -0.126004 & -0.313866 & 0.7553 \\
\hline R-squared & 0.694865 & Mean dependent var & -0.011250 \\
\hline Adjusted R-squared & 0.686835 & S.D. dependent var & 4.535011 \\
\hline S.E. of regression & 2.537842 & Akaike info criterion & 4.749212 \\
\hline Sum squared resid & 244.7445 & Schwarz criterion & 4.833656 \\
\hline Log likelihood & -92.98425 & Hannan-Quinn criter. & 4.779745 \\
\hline F-statistic & 86.53516 & Durbin-Watson stat & 2.343327 \\
\hline Prob(F-statistic) & 0.000000 & & \\
\hline
\end{tabular}

Null Hypothesis: GDPFC has a unit root

Exogenous: Constant, Linear Trend

Bandwidth: 4 (Newey-West automatic) using Bartlett kernel

\begin{tabular}{llcc}
\hline \hline & & Adj. t-Stat & Prob. $^{*}$ \\
\hline \hline Phillips-Perron test statistic & & 4.731493 & 1.0000 \\
\hline Test critical values: & 1\% level & -4.192337 & \\
& $5 \%$ level & -3.520787 & \\
& 10\% level & -3.191277 & \\
\hline \hline
\end{tabular}

*MacKinnon (1996) one-sided p-values.

Residual variance (no correction)

$1.23 \mathrm{E}+11$

HAC corrected variance (Bartlett kernel)

$1.81 \mathrm{E}+11$

Phillips-Perron Test Equation

Dependent Variable: D(GDPFC)

Method: Least Squares

Date: 07/20/17 Time: 11:06

Sample (adjusted): 19742015

Included observations: 42 after adjustments

\begin{tabular}{lrcrr}
\hline \hline \multicolumn{1}{c}{ Variable } & Coefficient & Std. Error & t-Statistic & Prob. \\
\hline \hline \multicolumn{1}{c}{ GDPFC(-1) } & 0.090413 & 0.015344 & 5.892231 & 0.0000 \\
C & -164966.9 & 135145.8 & -1.220659 & 0.2295 \\
\multicolumn{1}{c}{ @TREND("1973") } & 17612.15 & 7984.163 & 2.205886 & 0.0334 \\
\hline \hline R-squared & 0.822111 & Mean dependent var & 613334.9 \\
Adjusted R-squared & 0.812989 & S.D. dependent var & 841987.0 \\
S.E. of regression & 364115.5 & Akaike info criterion & 28.51708 \\
Sum squared resid & $5.17 \mathrm{E}+12$ & Schwarz criterion & 28.64120 \\
Log likelihood & -595.8587 & Hannan-Quinn criter. & 28.56257
\end{tabular}


F-statistic

Null Hypothesis: D(GDPFC) has a unit root

Exogenous: Constant, Linear Trend

Bandwidth: 5 (Newey-West automatic) using Bartlett kernel

\begin{tabular}{lccc}
\hline \hline & & Adj. t-Stat & Prob.* \\
\hline \hline Phillips-Perron test statistic & & -3.465816 & 0.0567 \\
\hline Test critical values: & 1\% level & -4.198503 & \\
& $5 \%$ level & -3.523623 & \\
& $10 \%$ level & -3.192902 & \\
\hline \hline
\end{tabular}

*MacKinnon (1996) one-sided p-values.

Residual variance (no correction)

$1.54 \mathrm{E}+11$

HAC corrected variance (Bartlett kernel)

$1.78 \mathrm{E}+11$

Phillips-Perron Test Equation

Dependent Variable: D(GDPFC,2)

Method: Least Squares

Date: 07/20/17 Time: 11:08

Sample (adjusted): 19752015

Included observations: 41 after adjustments

\begin{tabular}{lrlrr}
\hline \hline \multicolumn{1}{c}{ Variable } & Coefficient & Std. Error & t-Statistic & Prob. \\
\hline \hline \multicolumn{1}{c}{ D(GDPFC(-1)) } & -0.433961 & 0.130569 & -3.323621 & 0.0020 \\
C & -286961.2 & 157975.5 & -1.816491 & 0.0772 \\
@TREND("1973") & 26618.04 & 9008.399 & 2.954803 & 0.0053 \\
\hline \hline R-squared & 0.228907 & Mean dependent var & 46281.24 \\
Adjusted R-squared & 0.188323 & S.D. dependent var & 452439.0 \\
S.E. of regression & 407616.4 & Akaike info criterion & 28.74440 \\
Sum squared resid & $6.31 \mathrm{E}+12$ & Schwarz criterion & 28.86978 \\
Log likelihood & -586.2601 & Hannan-Quinn criter. & 28.79005 \\
F-statistic & 5.640345 & Durbin-Watson stat & 2.596339 \\
Prob(F-statistic) & 0.007162 & & \\
\hline \hline
\end{tabular}

Null Hypothesis: D(GDPFC,2) has a unit root

Exogenous: Constant, Linear Trend

Bandwidth: 3 (Newey-West automatic) using Bartlett kernel 


\begin{tabular}{lccc} 
& & Adj. t-Stat & Prob. $^{*}$ \\
\hline \hline Phillips-Perron test statistic & & -14.21641 & 0.0000 \\
\hline Test critical values: & 1\% level & -4.205004 & \\
& $5 \%$ level & -3.526609 & \\
& $10 \%$ level & -3.194611 & \\
\hline \hline
\end{tabular}

*MacKinnon (1996) one-sided p-values.

Residual variance (no correction)

Phillips-Perron Test Equation

Dependent Variable: D(GDPFC,3)

Method: Least Squares

Date: 07/20/17 Time: 11:10

Sample (adjusted): 19762015

Included observations: 40 after adjustments

\begin{tabular}{lrlrr}
\hline \hline \multicolumn{1}{c}{ Variable } & Coefficient & Std. Error & t-Statistic & Prob. \\
\hline \hline \multicolumn{1}{c}{ D(GDPFC(-1),2) } & -1.653627 & 0.129640 & -12.75551 & 0.0000 \\
\multicolumn{1}{c}{ QTREND("1973") } & -44402.88 & 125321.0 & -0.354313 & 0.7251 \\
\multicolumn{1}{c}{5813.116} & 4989.124 & 1.165158 & 0.2514 \\
\hline \hline R-squared & 0.814913 & Mean dependent var & -12282.70 \\
Adjusted R-squared & 0.804908 & S.D. dependent var & 818034.3 \\
S.E. of regression & 361319.0 & Akaike info criterion & 28.50495 \\
Sum squared resid & $4.83 E+12$ & Schwarz criterion & 28.63161 \\
Log likelihood & -567.0990 & Hannan-Quinn criter. & 28.55075 \\
F-statistic & 81.45303 & Durbin-Watson stat & 2.460604 \\
Prob(F-statistic) & 0.000000 & & \\
\hline \hline
\end{tabular}




\begin{tabular}{|c|c|c|c|c|}
\hline $\begin{array}{l}\text { Autoregressive Dist } \\
\text { Dependent Variable: } \\
\text { Method: ARDL } \\
\text { Date: } 07 / 20 / 17 \text { Tim } \\
\text { Sample (adjusted): } 1 \\
\text { Included observation } \\
\text { Maximum dependent } \\
\text { Model selection meth } \\
\text { Dynamic regressors } \\
\text { Fixed regressors: C } \\
\text { Number of models e } \\
\text { Selected Model: ARL } \\
\text { Note: final equation } s\end{array}$ & $\begin{array}{l}\text { ag (ARDL) I } \\
\text { adjustments } \\
\text { utomatic sele } \\
\text { info criterion } \\
\text { tomatic): GD } \\
100 \\
\text { arger than se }\end{array}$ & $\begin{array}{l}\text { ction) } \\
\text { (AIC) } \\
\text { PFC CMR } \\
\\
\text { ection sample }\end{array}$ & & \\
\hline Variable & Coefficient & Std. Error & t-Statistic & Prob.* \\
\hline GTINV(-1) & 1.177766 & 0.138666 & 8.493529 & 0.0000 \\
\hline GTINV(-2) & -0.277743 & 0.227353 & -1.221634 & 0.2311 \\
\hline GTINV(-3) & -0.466340 & 0.210595 & -2.214391 & 0.0343 \\
\hline GDPFC & 0.111931 & 0.047637 & 2.349656 & 0.0253 \\
\hline GDPFC(-1) & 0.068840 & 0.045690 & 1.506681 & 0.1420 \\
\hline GDPFC(-2) & -0.115911 & 0.042052 & -2.756369 & 0.0097 \\
\hline CMR & 7783.818 & 6908.784 & 1.126655 & 0.2685 \\
\hline $\operatorname{CMR}(-1)$ & -20234.96 & 6555.669 & -3.086636 & 0.0042 \\
\hline C & 130288.2 & 39244.05 & 3.319947 & 0.0023 \\
\hline R-squared & 0.998083 & Mean dependent var & & 924288.1 \\
\hline Adjusted R-squared & 0.997588 & S.D. dependent var & & 1170641. \\
\hline S.E. of regression & 57487.51 & Akaike info criterion & & 24.95163 \\
\hline Sum squared resid & $1.02 \mathrm{E}+11$ & Schwarz criterion & & 25.33163 \\
\hline Log likelihood & -490.0326 & Hannan-Quinn criter. & & 25.08903 \\
\hline F-statistic & 2017.632 & Durbin-Watson stat & & 2.014121 \\
\hline Prob(F-statistic) & 0.000000 & & & \\
\hline
\end{tabular}

${ }^{*}$ Note: $p$-values and any subsequent tests do not account for model selection.

ARDL Bounds Test

ARDL Bounds Test

Date: 07/20/17 Time: 11:25

Sample: 19762015

Included observations: 40

Null Hypothesis: No long-run relationships exist

\begin{tabular}{lll}
\hline \hline Test Statistic & Value & $\mathrm{k}$ \\
\hline \hline F-statistic & 7.108539 & 2 \\
\hline \hline
\end{tabular}

Critical Value Bounds 


\begin{tabular}{lcc} 
Significance & I0 Bound & I1 Bound \\
\hline \hline $10 \%$ & 2.63 & 3.35 \\
$5 \%$ & 3.1 & 3.87 \\
$2.5 \%$ & 3.55 & 4.38 \\
$1 \%$ & 4.13 & 5 \\
\hline \hline
\end{tabular}

Test Equation:

Dependent Variable: D(GTINV)

Method: Least Squares

Date: 07/20/17 Time: 11:25

Sample: 19762015

Included observations: 40

\begin{tabular}{lrcrr}
\hline \hline \multicolumn{1}{c}{ Variable } & Coefficient & Std. Error & t-Statistic & Prob. \\
\hline \hline D(GTINV(-1)) & 0.744082 & 0.174558 & 4.262670 & 0.0002 \\
D(GTINV(-2)) & 0.466340 & 0.210595 & 2.214391 & 0.0343 \\
D(GDPFC) & 0.111931 & 0.047637 & 2.349656 & 0.0253 \\
D(GDPFC(-1)) & 0.115911 & 0.042052 & 2.756369 & 0.0097 \\
D(CMR) & 7783.818 & 6908.784 & 1.126655 & 0.2685 \\
C & 130288.2 & 39244.05 & 3.319947 & 0.0023 \\
GDPFC(-1) & 0.064859 & 0.016957 & 3.824965 & 0.0006 \\
CMR(-1) & -12451.14 & 4515.266 & -2.757566 & 0.0097 \\
GTINV(-1) & -0.566316 & 0.170439 & -3.322690 & 0.0023 \\
\hline \hline R-squared & 0.867562 & Mean dependent var & & 103044.5 \\
Adjusted R-squared & 0.833385 & S.D. dependent var & & 140836.8 \\
S.E. of regression & 57487.51 & Akaike info criterion & & 24.95163 \\
Sum squared resid & $1.02 E+11$ & Schwarz criterion & & 25.33163 \\
Log likelihood & -490.0326 & Hannan-Quinn criter. & & 25.08903 \\
F-statistic & 25.38403 & Durbin-Watson stat & & \\
Prob(F-statistic) & 0.000000 & & \\
\hline \hline
\end{tabular}

ARDL Cointegrating and Long Run Form

ARDL Cointegrating And Long Run Form

Dependent Variable: GTINV

Selected Model: ARDL $(3,2,1)$

Date: 07/20/17 Time: 11:25

Sample: 19732015

Included observations: 40

Cointegrating Form

\begin{tabular}{ccccc}
\hline \hline Variable & Coefficient & Std. Error & t-Statistic & Prob. \\
\hline \hline $\mathrm{D}($ GTINV(-1)) & 0.744082 & 0.119328 & 6.235594 & 0.0000
\end{tabular}




\begin{tabular}{crrrr} 
D(GTINV(-2)) & 0.466340 & 0.160062 & 2.913489 & 0.0066 \\
D(GDPFC) & 0.111931 & 0.026969 & 4.150364 & 0.0002 \\
D(GDPFC(-1)) & 0.115911 & 0.025149 & 4.608994 & 0.0001 \\
D(CMR) & 7783.818128 & 5001.831238 & 1.556194 & 0.1298 \\
CointEq(-1) & -0.566316 & 0.101410 & -5.584429 & 0.0000 \\
\hline
\end{tabular}

Cointeq $=$ GTINV $-\left(0.1145^{*}\right.$ GDPFC $-21986.2130^{*}$ CMR +230062.6942$)$

Long Run Coefficients

\begin{tabular}{crrrr}
\hline \hline Variable & Coefficient & Std. Error & t-Statistic & Prob. \\
\hline \hline GDPFC & 0.114528 & 0.012333 & 9.286608 & 0.0000 \\
CMR & -21986.2130 & 10469.175659 & -2.100090 & 0.0440 \\
C & 230062.6942 & 95568.140547 & 2.407316 & 0.0222 \\
\hline \hline
\end{tabular}

Plot of Cumulative Sum of Recursive Residuals

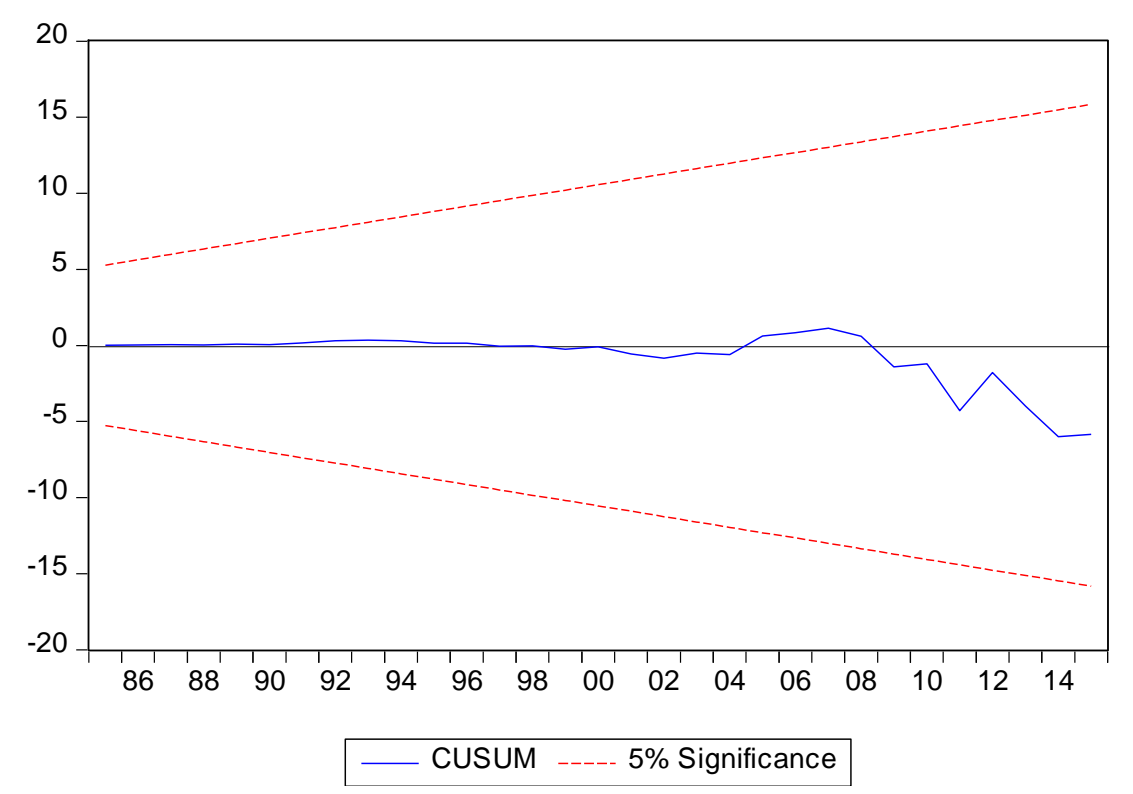


Breusch-Godfrey Serial Correlation LM Test

Breusch-Godfrey Serial Correlation LM Test:

\begin{tabular}{llll}
\hline \hline F-statistic & 0.081078 & Prob. F(2,29) & 0.9223 \\
Obs*R-squared & 0.222419 & Prob. Chi-Square(2) & 0.8948 \\
\hline \hline
\end{tabular}

Test Equation:

Dependent Variable: RESID

Method: ARDL

Date: 07/20/17 Time: 18:02

Sample: 19762015

Included observations: 40

Presample missing value lagged residuals set to zero.

\begin{tabular}{crcrc}
\hline \hline Variable & Coefficient & Std. Error & t-Statistic & Prob. \\
\hline \hline GTINV(-1) & -0.024804 & 0.231698 & -0.107055 & 0.9155 \\
GTINV(-2) & 0.077253 & 0.409332 & 0.188730 & 0.8516 \\
GTINV(-3) & -0.070531 & 0.310901 & -0.226859 & 0.8221 \\
CMR & 4.060724 & 7168.522 & 0.000566 & 0.9996 \\
CMR(-1) & -47.91866 & 6911.703 & -0.006933 & 0.9945 \\
GDPFC & -0.000148 & 0.050237 & -0.002939 & 0.9977 \\
GDPFC(-1) & 0.007446 & 0.057434 & 0.129647 & 0.8977 \\
GDPFC(-2) & -0.005854 & 0.046990 & -0.124590 & 0.9017 \\
C & 56.06966 & 41310.79 & 0.001357 & 0.9989 \\
RESID(-1) & 0.016884 & 0.301357 & 0.056027 & 0.9557 \\
RESID(-2) & -0.108604 & 0.273146 & -0.397604 & 0.6938 \\
\hline \hline \multirow{2}{*}{ R-squared } & 0.005560 & Mean dependent var & $-1.84 \mathrm{E}-11$ \\
Adjusted R-squared & -0.337350 & S.D. dependent var & 51253.32 \\
S.E. of regression & 59271.31 & Akaike info criterion & 25.04605 \\
Sum squared resid & $1.02 \mathrm{E}+11$ & Schwarz criterion & 25.51050 \\
Log likelihood & -489.9211 & Hannan-Quinn criter. & 25.21398 \\
F-statistic & 0.016216 & Durbin-Watson stat & 1.992990 \\
Prob(F-statistic) & 1.000000 & & & \\
\hline \hline
\end{tabular}

Heteroskedasticity Test: White

Heteroskedasticity Test: White

\begin{tabular}{llll}
\hline \hline F-statistic & 1.192679 & Prob. F(8,31) & 0.3351 \\
Obs*R-squared & 9.414007 & Prob. Chi-Square(8) & 0.3086 \\
Scaled explained SS & 6.653107 & Prob. Chi-Square(8) & 0.5745 \\
\hline \hline
\end{tabular}

Test Equation:

Dependent Variable: RESID^2 
Method: Least Squares

Date: 07/20/17 Time: 18:05

Sample: 19762015

Included observations: 40

\begin{tabular}{|c|c|c|c|c|}
\hline Variable & Coefficient & Std. Error & t-Statistic & Prob. \\
\hline C & $2.25 \mathrm{E}+09$ & $1.64 \mathrm{E}+09$ & 1.365135 & 0.1820 \\
\hline $\operatorname{GTINV}(-1)^{\wedge} 2$ & $-2.14 \mathrm{E}-05$ & 0.002343 & -0.009118 & 0.9928 \\
\hline $\operatorname{GTINV}(-2)^{\wedge} 2$ & 0.003824 & 0.003925 & 0.974416 & 0.3374 \\
\hline 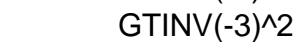 & -0.005090 & 0.003600 & -1.414013 & 0.1673 \\
\hline $\mathrm{CMR}^{\wedge} 2$ & -1604592 & 23592795 & -0.068012 & 0.9462 \\
\hline $\operatorname{CMR}(-1)^{\wedge} 2$ & -4112018 & 21200537 & -0.193958 & 0.8475 \\
\hline GDPFC^2 & $8.35 E-05$ & $8.99 \mathrm{E}-05$ & 0.929697 & 0.3597 \\
\hline $\operatorname{GDPFC}(-1)^{\wedge} 2$ & $6.23 \mathrm{E}-05$ & 0.000101 & 0.613589 & 0.5440 \\
\hline $\operatorname{GDPFC}(-2)^{\wedge} 2$ & -0.000193 & 0.000111 & -1.736353 & 0.0924 \\
\hline R-squared & 0.235350 & \multicolumn{2}{|l|}{ Mean dependent var } & $2.56 \mathrm{E}+09$ \\
\hline Adjusted R-squared & 0.038021 & & $3.98 \mathrm{E}+09$ \\
\hline S.E. of regression & $3.90 \mathrm{E}+09$ & \multicolumn{2}{|l|}{ Akaike info criterion } & 47.20286 \\
\hline Sum squared resid & $4.72 \mathrm{E}+20$ & \multicolumn{2}{|l|}{ Schwarz criterion } & 47.58286 \\
\hline Log likelihood & -935.0573 & \multirow{2}{*}{\multicolumn{2}{|c|}{ Hannan-Quinn criter. }} & 47.34026 \\
\hline F-statistic & 1.192679 & \multirow{2}{*}{\multicolumn{2}{|c|}{ Durbin-Watson stat }} & 1.908723 \\
\hline Prob(F-statistic) & 0.335117 & & & \\
\hline
\end{tabular}

Heteroskedasticity Test: ARCH

Heteroskedasticity Test: ARCH

\begin{tabular}{llll}
\hline \hline F-statistic & 1.191418 & Prob. $F(1,37)$ & 0.2821 \\
Obs ${ }^{*}$-squared & 1.216642 & Prob. Chi-Square(1) & 0.2700 \\
\hline \hline
\end{tabular}


Test Equation:

Dependent Variable: RESID^2

Method: Least Squares

Date: 07/20/17 Time: 18:07

Sample (adjusted): 19772015

Included observations: 39 after adjustments

\begin{tabular}{lrccr}
\hline \hline \multicolumn{1}{c}{ Variable } & Coefficient & Std. Error & t-Statistic & Prob. \\
\hline \hline \multicolumn{1}{c}{ C } & $2.16 \mathrm{E}+09$ & $7.69 \mathrm{E}+08$ & 2.811057 & 0.0079 \\
\multicolumn{1}{c}{ RESID^2(-1) } & 0.176658 & 0.161846 & 1.091521 & 0.2821 \\
\hline \hline R-squared & 0.031196 & Mean dependent var & $2.62 \mathrm{E}+09$ \\
Adjusted R-squared & 0.005012 & S.D. dependent var & $4.01 \mathrm{E}+09$ \\
S.E. of regression & $4.00 \mathrm{E}+09$ & Akaike info criterion & 47.10709 \\
Sum squared resid & $5.92 \mathrm{E}+20$ & Schwarz criterion & 47.19240 \\
Log likelihood & -916.5883 & Hannan-Quinn criter. & 47.13770 \\
F-statistic & 1.191418 & Durbin-Watson stat & 2.101371 \\
Prob(F-statistic) & 0.282101 & & \\
\hline \hline
\end{tabular}

\section{Jarque Bera Test for Residuals Normal Distribution}

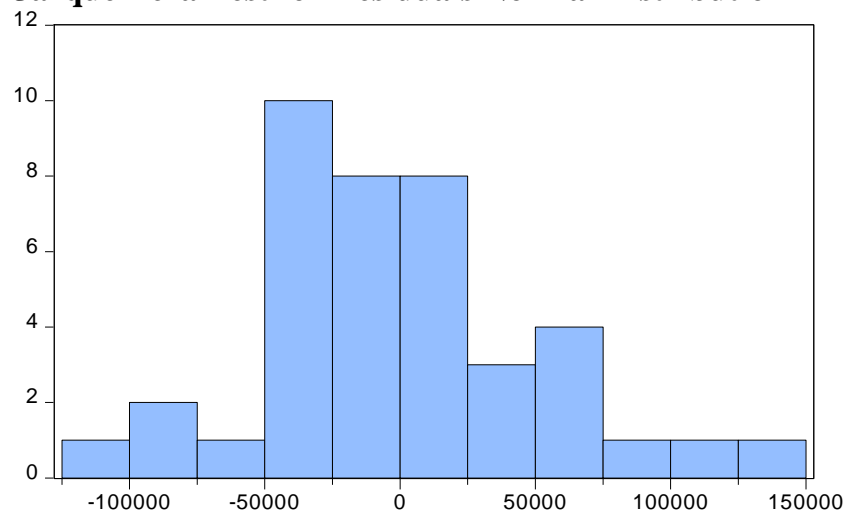

Series: Residuals

Sample 19762015

Observations 40

Mean $\quad-1.84 \mathrm{e}-11$

Median $\quad-10530.28$

Maximum 133524.3

Minimum $\quad-100968.9$

Std. Dev. $\quad 51253.32$

Skewness 0.669006

Kurtosis $\quad 3.353296$

Jarque-Bera 3.191827

Probability $\quad 0.202723$ 